\title{
Ommastrephid squid spawning in the North Sea: oceanography, climate change and species range expansion
}

\author{
Christopher J. Barrett ${ }^{1}$, Eleanor MacLeod ${ }^{1}$, Daniel Oesterwind ${ }^{2}$, Vladimir Laptikhovsky ${ }^{1}$ \\ ${ }^{1}$ Cefas, Pakefield Road, Lowestoft, Suffolk, NR33 0HT, England, UK. \\ (CJB) E-mail: christopher.barrett@ cefas.co.uk. ORCID iD: https://orcid.org/0000-0003-3157-4595 \\ (EM) E-mail: eleanor.macleod@ @efas.co.uk. ORCID iD: https://orcid.org/0000-0002-2843-501X \\ (VL) (Corresponding author) E-mail: vladimir.laptikhovsky@ cefas.co.uk. ORCID iD: https://orcid.org/0000-0001-6965-8327 \\ ${ }^{2}$ Thünen Institute of Baltic Sea Fisheries, Alter Hafen Süd 2, D-18069, Rostock, Germany. \\ (DO) E-mail: daniel.oesterwind@thuenen.de. ORCID iD: https://orcid.org/0000-0002-1093-4283
}

\begin{abstract}
Summary: The lesser flying squid (Todaropsis eblanae) and the shortfin squid (Illex coindetii) are two abundant ommastrephids of the northeast Atlantic. Spawning ground existence was inferred from the captures of mature, mated females in summer 2016-2019 and their occurrences were compared with respective oceanographic data from international surveys to gain insight into environmental predictors of their presence throughout the North Sea. Spawning T. eblanae were found in relatively cooler and more saline waters $\left(6-8^{\circ} \mathrm{C}, 34.2-35.1 \mathrm{psu}\right)$ in the northern North Sea linked to the Fair Isle Current and East Shetland Atlantic Inflow, whilst spawning I. coindetii occurred across the entire North Sea (mostly at $9-10.5^{\circ} \mathrm{C}$, 34.1-34.8 psu). We hypothesize that a combination of water salinity and water temperature are key factors in the spatiotemporal distribution of spawning ommastrephid squids as they define water density that is crucial for pelagic egg mass to attain neutral buoyancy.
\end{abstract}

Keywords: squids; North Sea; oceanography; spawning; Illex coindetii; Todaropsis eblanae.

Desove de calamares ommastréfidos en el mar del Norte: oceanografía, cambio climático y ampliación del rango de distribución de especies

Resumen: La pota costera (Todaropsis eblanae) y la pota voladora (Illex coindetii) son dos ommastréfidos abundantes del Atlántico nororiental. La existencia de una zona de desove se ha inferido a partir de capturas de hembras maduras y copuladas durante los veranos de 2016-2019. Su presencia se ha comparado con datos oceanográficos de estudios internacionales para conocer los predictores ambientales de su presencia en el Mar del Norte. El desove de T. eblanae se halló en aguas relativamente frías y salinas $\left(6-8^{\circ} \mathrm{C}, 34,2-35,1 \mathrm{psu}\right)$ del norte del Mar del Norte, vinculadas a la corriente de Fair Isle y el aporte de aguas atlánticas provenientes de Este de las Shetland. El desove de I. coindetii aconteció en todo el Mar del Norte (principalmente entre $\operatorname{los} 9-10.5^{\circ} \mathrm{C}, 34,1-34.8 \mathrm{psu}$ ). Se sugiere que una combinación de salinidad y temperatura del agua son factores clave en la distribución espacio-temporal de los calamares ommastréfidos desovantes, ya que la densidad del agua es crucial para que las masas de huevos pelágicos alcancen una flotabilidad neutra.

Palabras clave: calamares; mar del Norte; oceanografía; desove; Illex coindetii; Todaropsis eblanae.

Citation/Como citar este artículo: Barrett C.J., MacLeod E., Oesterwind D., Laptikhovsky V. 2021. Ommastrephid squid spawning in the North Sea: oceanography, climate change and species range expansion. Sci. Mar. 85(1): 49-56. https://doi.org/https://doi.org/10.3989/scimar.05065.005

Editor: R. Villanueva.

Received: October 23, 2020. Accepted: December 16, 2020. Published: March 31, 2021.

Copyright: () 2021 CSIC. This is an open-access article distributed under the terms of the Creative Commons Attribution 4.0 International (CC BY 4.0) License. 


\section{INTRODUCTION}

World-wide, cephalopods are expanding their ranges and increasing in numbers. This "bloom" is seen in all ecological groups (demersal, benthopelagic and pelagic) and in all major taxonomic groups: octopods, cuttlefishes and squids (Doubleday et al. 2016). Among cephalopods, ommastrephid squids represent most of the commercial squid catch (and presumably the highest biomass), accounting in $2015-2019$ for at least $49.8 \%$ to $65.9 \%$ of the total squid catch and at least $32.7 \%$ to $48.9 \%$ of the total cephalopod catch (FAO 2020).

Therefore, squids are not only the most diverse but also the most commercially and ecologically important cephalopods. Shelf waters down to 100 to $200 \mathrm{~m}$ depth are dominated by inshore nektonic squids of the suborder Myopsida (Nesis 1985). Some myopsid squids might occur occasionally in waters deeper than $200 \mathrm{~m}$, and even descend to 700-800 m like Loligo forbesii (Salman and Laptikhovsky 2002) and Doryteuthis gahi (Laptikhovsky 2007), but their main distribution ranges and most of their spawning grounds are still on the shallow shelf. Epipelagic oceanic waters with bottoms deeper than $200 \mathrm{~m}$ are inhabited by squids of the suborder Oegopsida that also inhabit mesoand bathypelagial waters. Only two genera of oegopsid squid (Illex and Todaropsis) containing a handful of species made the shelf of the Atlantic Ocean their permanent habitat for at least most of their life cycle, though they were also abundant on the slope. In the North Pacific, they are substituted by an ecological equivalent, Todarodes pacificus, which have a habitat and migrations similar to those of Illex and different from those of the congeneric Atlantic T. sagittatus, T. filippovae and T. angolensis inhabiting shelf edges, slopes and offshore seamounts (Nigmatullin and Laptikhovsky 1999, Nigmatullin 2007).

The shortfin squid Illex coindetii is a neritic species with distribution covering both sides of the Atlantic and the Mediterranean Sea, mostly between 50 to 100 and 400 to $600 \mathrm{~m}$ but reaching down to $1000 \mathrm{~m}$ (González et al. 1996, Jereb et al. 2015). The lesser flying squid, T. eblanae, occurs in East Atlantic waters with bottom depths of 20 to 700 m (Roper et al. 2010) from Norway to South Afri$\mathrm{ca}$, including the Mediterranean Sea and occurring patchily in some areas of the Indo-Pacific (Belcari et al. 2015).

In the Northeast Atlantic both species inhabit the same fishing grounds and have nearly the same range of bathymetric distribution. They are close in morphology and size and both are considered opportunistic predators whose diet consists mainly of demersal fishes. They co-occur in the same habitat and the fauna of their parasites is very similar (Rasero et al. 1996, Pascual et al. 1996).

In recent decades ommastrephids have expanded their ranges and increased in numbers in the North Sea (Kooij et al. 2016). Most recently, I. coindetii has begun to reproduce there and has entered the Baltic Sea (Oesterwind and Schaber 2020, Oesterwind et al. 2020). Like I. coindetii, T. eblanae was rare in the North Sea in the early twentieth century, as Grimpe (1925) mentioned only three reliable records of $T$. eblanae individuals. In recent decades, it has not only settled in the North Sea but has been found to stray into north Norwegian and Russian waters of the Barents Sea, up to $71^{\circ} \mathrm{N}$, including mature males (Golikov et al. 2012, Sabirov et al. 2012), thus becoming the first ommastrephid squid to cross the Polar circle. However, the North Sea appears to be the coldest edge of the reproduction range of the generally subtropical $I$. coindetii and T. eblanae, for which temperate waters represent the periphery of their ranges. Unsurprisingly, both species reproduce in the North Sea mainly in summer (Hastie et al. 1994, González and Guerra 1996, Oesterwind et al. 2015). Summer is also the normal peak of spawning of $I$. coindetii in more southern waters of the Northeast Atlantic (González and Guerra 1996).

In general, there is no information on spawning grounds and environmental spawning requirements of the two species throughout their distribution ranges. However, all known ommastrephid squids produce pelagic, spherical egg masses that contain thousands of eggs that drift with the currents in the subsurface pelagic layer at some depth, where their buoyancy is neutral (Laptikhovsky and Murzov 1990, O'Shea et al. 2004, Staaf et al. 2008). Egg development of Illex spp. takes 4 to 16 days depending on temperature (O'Dor and Balch 1984, Villanueva et al. 2011). Measurements of rates of temperature equilibration between ommastrephid egg masses and the surrounding water suggest that complete density levelling requires many days after spawning (O'Dor and Balch 1984) in order for eggs to develop. During this period, the egg mass might be carried a considerable distance, particularly if it drifts in a strong current.

In the open ocean, ommastrephid egg masses have little risk of being washed onshore, so squids of the genus Sthenoteuthis, Ommastrephes, Dosidicus, Hyaloteuthis and Eucleoteuthis are seldom confronted with this risk. Slope species such as the Atlantic Todarodes spp. and Ornitoteuthis antillarum reproduce mostly at the offshore side of boundary currents (e.g. the Canary, Benguela, Brazil and Falkland currents), which also protect egg masses from being transported onto the coast (Nigmatullin and Laptikhovsky 1994). These meridional currents are also used by the western Atlantic $I$. argentinus and I. illecebrosus for spawning on the inshore side (Nigmatullin and Laptikhovsky 1994). Boundary currents also exhibit a strong vertical water structure, simplifying the appearance of a "liquid bottom" that prevents egg masses not only from being washed onshore but also from sinking to the sea floor.

The situation might be different in semi-enclosed shallow seas. The North Sea is bordered by Great 
Britain to the east, France, Belgium, Netherlands and Germany to the south and Denmark, Sweden and Norway to the east, so shorelines are relatively close in nearly every direction. Moreover, the average depth of the sea is only $90 \mathrm{~m}$ (Calow 1999), with shallower waters in the south and deeper waters in the north. Considering that sea water convection (mixing) caused by wind waves expands down to tens of metres and swell to hundreds of metres (Moum and Smyth 2001), it is difficult to imagine how ommastrephid squids in the North Sea rely on a stable density layer (thermocline or halocline). The question is how do ommastrephids survive and increase in numbers, as was testified recently by the survey data (Kooij et al. 2016) and by the fact that their numerous egg masses have been observed there more frequently in recent years (Ringvold and Taite 2018).

Based on survey data and maps displaying potential spawning habitats according to temperature, salinity and density requirements, this study identifies for the first-time spawning grounds of I. coindetii and T. eblanae. This information on spawning habitats will support a science-based development of a virtually non-existent regional cephalopod fisheries management and allow other human ecosystem services to be in line with an ecosystem-based management approach. Furthermore, it will fill an important knowledge gap in the ecology of both species in the North Sea.

\section{METHODS}

Between 2016 and 2019, 262 mature I. coindetii (150 males, 112 females) and 17 mature T. eblanae (11 males, 6 females) were sampled between July and September (Table 1) during the ICES coordinated North Sea - International Bottom Trawl Survey (NS-IBTS) (for detailed survey information see ICES 2018). All specimens were frozen on board and taken to the CEFAS or Thünen laboratory, depending on the survey. There, individuals were defrosted, weighed, measured (dorsal mantle length to the nearest $\mathrm{mm}$ ) and sexed, and the maturity stages were assigned according to Lipinski's five-stage maturity scale (Lipinski 1979).

Temperature and salinities at various depths across the entire North Sea (Fig. 1) were downloaded from the ICES dataset on Ocean Hydrography from 2016 to 2019. These data were imported into Ocean Data View (Schlitzer 2014), which was

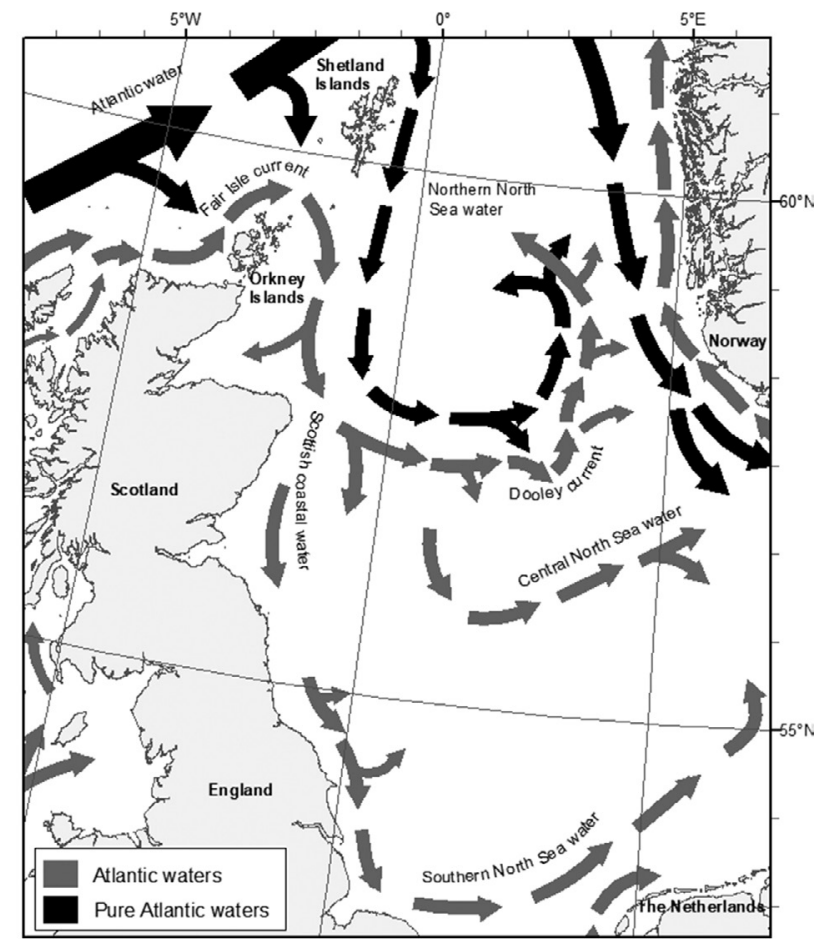

Fig. 1. - Scheme of currents in the North Sea (adapted from Paramor et al. 2009).

used to map oceanographic parameters. A $40 \mathrm{~km}-$ wide transect drawn from the Shetland Islands to the Netherlands was used to define exact latitudinal position of currents within the North Sea (Fig. 2) and was combined with oceanographic maps using ArcGIS 10.5 (ESRI 2011) to explain the distribution of mature squid during the spawning period.

\section{RESULTS}

\section{Oceanography}

A comparison of the oceanographic condition between the studied years indicated very little interannual variability in temperature and salinity across the defined transect, which allowed us to combine data (Fig. 2).

A clear thermocline that represents a potential layer for pelagic egg masses was observed between 20 and $50 \mathrm{~m}$ depth and spanned from the area around 100 $\mathrm{km}$ south of the Shetland Islands to European shores

Table 1. - Biological characteristics of mature I. coindetii and T. eblanae sampled in the North Sea. Lengths (dorsal mantle length) are measured in millimetres and weights in grams. Some T. eblanae were not weighed so summary of weight is not provided.

\begin{tabular}{lccrrrrrr}
\hline \multicolumn{1}{c}{ Species } & Sex & $\begin{array}{r}\text { Max. } \\
\text { length }\end{array}$ & $\begin{array}{r}\text { Min. } \\
\text { length }\end{array}$ & Mean length & $\begin{array}{r}\text { Max. } \\
\text { weight }\end{array}$ & Min. weight & Mean weight & Number \\
\hline Illex coindetii & F & 206 & 119 & 158.06 & 266.9 & 48.4 & 135.31 & 112 \\
& M & 182 & 84 & 131.95 & 163.2 & 46.6 & 97.26 & 150 \\
Todaropsis eblanae & F & 160 & 140 & 150 & NA & NA & NA & 6 \\
& M & 148 & 112 & 124.25 & 172 & 103 & 121.95 & 11 \\
\hline
\end{tabular}



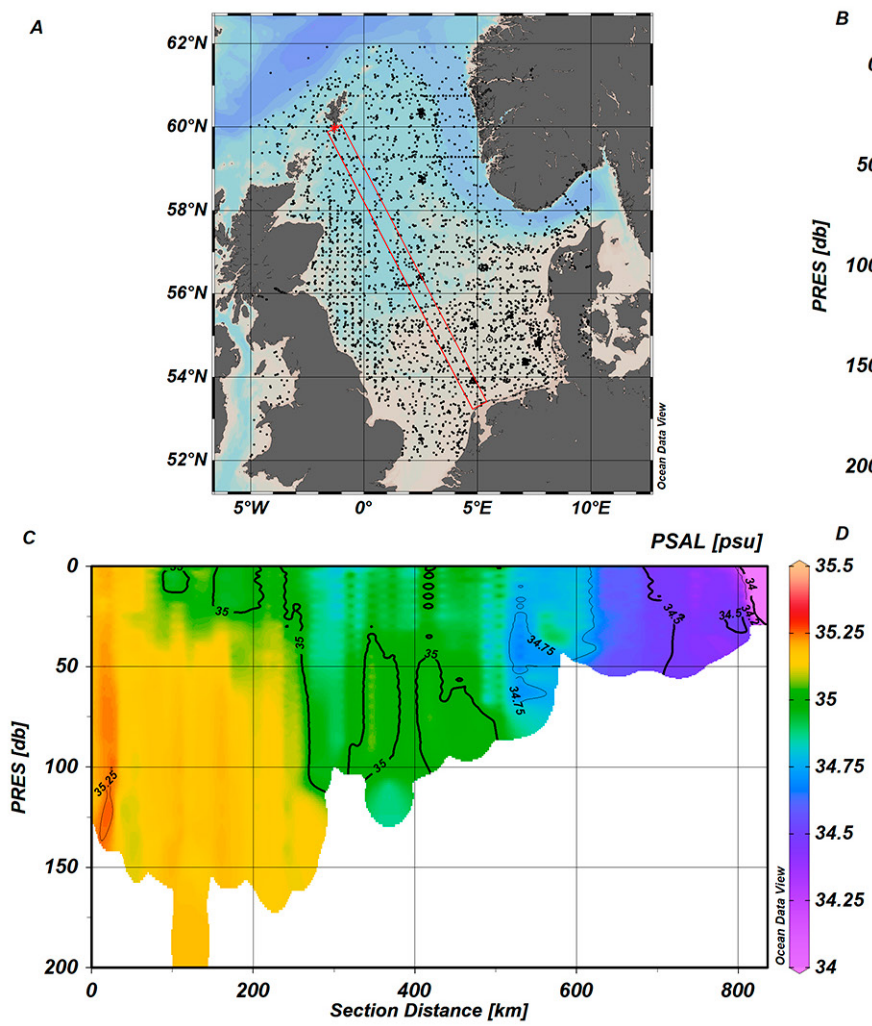
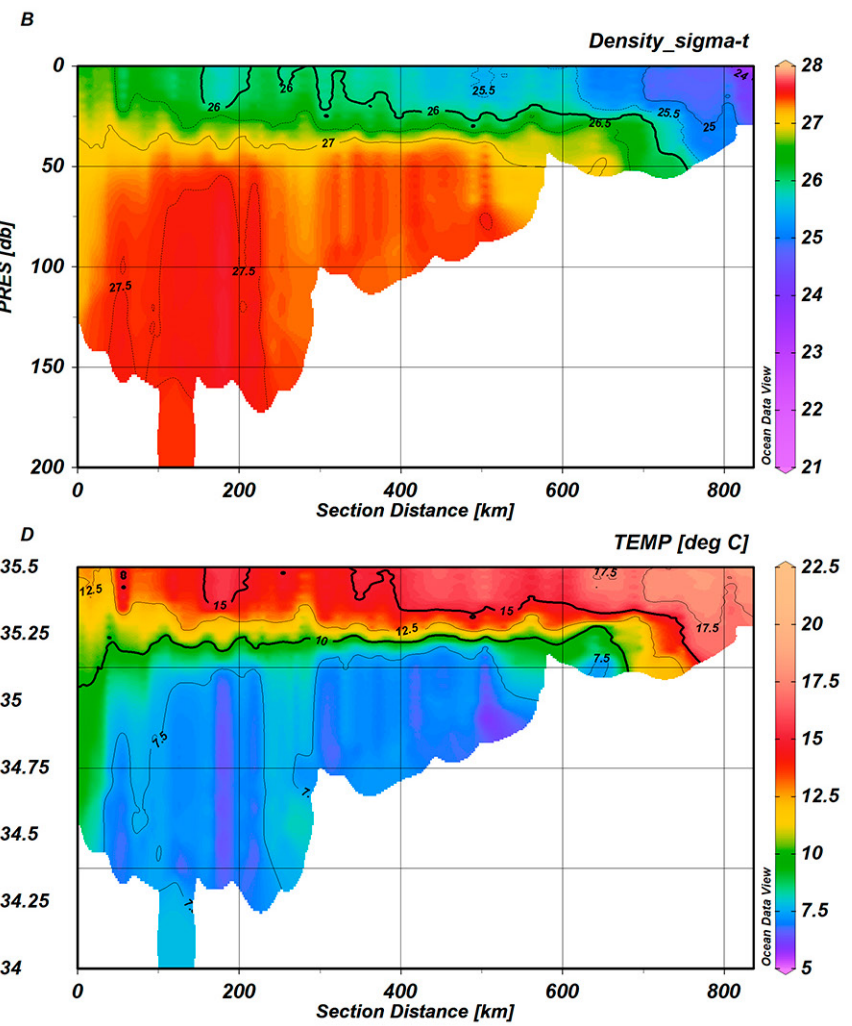

Fig. 2. - Position of the transect across the North Sea and distribution of temperature, salinity and density along it.

until it touched the bottom at a depth of around $50 \mathrm{~m}$ some 200-250 km off the mainland shores. Temperature increased from north to south. Salinity tended to decrease in the same direction due to riverine inflow from the European continent and the British Isles. Distinct pockets of more saline and dense Atlantic water corresponding to principal currents were clearly seen (Fig. 2). The northern part of the transect crossed colder and more saline northern North Sea waters until the distance of $250 \mathrm{~km}$ from the initial point of the transect, with a pocket of warmer and more saline water on the top in the central part of the eddy that originated from the Dooley Current. The relatively warm and saline Dooley and Central North Sea water current occurred some $250-300 \mathrm{~km}$ and $\sim 500 \mathrm{~km}$ south from the initial point of the transect, with southern North Sea water crossing the shelf approximately along the isobath of $50 \mathrm{~m}$, some 550 to $600 \mathrm{~km}$ from the Shetland Islands.

\section{Squid distribution}

Mature T. eblanae and I. coindetii (Table 1) were found at locations with bottom temperatures of $7.6^{\circ} \mathrm{C}$ to $9.8^{\circ} \mathrm{C}$. While mature $I$. coindetii are found in waters with a salinity of between 34.7 and 35.1, mature T. eblanae occupy a salinity range of 35.0 to 35.2 . Illex coindetii were present at depths of 29 to $175.5 \mathrm{~m}$ (mean $=69.7 \mathrm{~m}, 1^{\text {st }}$ quartile $=40.5 \mathrm{~m}, 3^{\text {rd }}$ quartile $=100.25$ m). T. eblanae were found at depths of 29 to $108.5 \mathrm{~m}$ $\left(\right.$ mean $=87.8 \mathrm{~m}, 1^{\text {st }}$ quartile $=74.18 \mathrm{~m}, 3^{\text {rd }}$ quartile $=$ $104.95 \mathrm{~m})$.
The distribution of both mature males and mature females of both species (Fig. 3) is unmistakably linked to the Fair Island Current and its extension - flow of the Scottish coastal water in the North Sea. They were captured all the way along Scottish shores. I. coindetii followed this current until it become southern North Sea water and began to move along European shores. T. eblanae dropped off the current earlier at the level of the Dooley Current.

\section{DISCUSSION}

As ommastrephids often carry out long-distance foraging migrations and males mature earlier than females (Rodhouse et al. 2014), the exact spawning time and place might not be assessed from captures of just mature squids that might be not ready to lay eggs. Such a readiness might be revealed by presence of fresh signs of copulation. In our study the readiness of females to spawn was very obvious because all of them were in spawning conditions with oviducts full of ripe eggs and spermatangia attached inside the mantle cavity in Illex and on the buccal membrane (including seminal receptacles) in Todaropsis. These seminal receptacles were white and therefore full of sperm, though we did not control this finding histologically. We therefore assumed that spawning egg release of females of both species might take place any moment. This assumption was based particularly on the fact that ommastrephid spermatagia do not remain intact upon 
ejaculation, and if not used they begin to gradually loose sperm. This process is clearly seen as a sperm "tail" trailing from a spermatangium 40 to 45 mins after ejaculation in Sthenoteuthis pteropus, and full emptying of a spermatangium takes from 5 hours at $28^{\circ} \mathrm{C}$ to $29^{\circ} \mathrm{C}$ to 40 to 60 hours at $8^{\circ} \mathrm{C}$ (Laptikhovsky 2011). A similar process was described in Todarodes pacificus (Soeda 1956) and Loligo pealei, in which the complete sperm escapement takes two days or more (Drew 1911). In Idiosepius paradoxus this discharge begins a few minutes after ejaculation but slows down after one hour; in 24 hours some $75.4 \%$ of spermatangia are already empty (Sato et al. 2014). However, there is evidence that in some sepiolids the sperm might be retained for as long as 145 days (Squires et al. 2014).

For the development of its pelagic egg masses, I. coindetii used the larger, outer gyre going all the way along shores of Scotland, England, Belgium, Netherlands, Denmark, Sweden and Norway. In Norway waters these egg masses were recorded in numbers by recreational divers and were interpreted as belonging to Todarodes sagittatus (Ringvold and Taite 2018), which reproduces on the Mid-Atlantic ridge and is now a very rare immature foraging migrant in the North Sea (Laptikhovsky 2013, Oesterwind et al. 2010, 2015). Oesterwind et al. (2020) assumed that the egg masses in North Sea waters and surroundings belong to I. coindetii, which has now been confirmed by $\mathrm{H}$. Ringvold through genetic identification of egg masses (Sea Snack Norway 2019).

T. eblanae takes a shortcut through a smaller gyre shaped by the Faire Isle Current, the Dooley Current and northern North Sea water. Some spawning I. coindetii likely also follow this way. Separation of spawning grounds between two simultaneously spawning generalistic predatory ommastrephid species (Rasero et al. 1996) likely helps to diminish interspecific competition and predation among early juveniles. T. eblanae is known to have the lowest fecundity among all ommastrephid squids combined with the largest (relatively) nidamental glands that produce the gel containing egg mass (Rasero et al. 1995). The functional meaning of this phenomenon is unclear and might be related to the ability to produce egg masses in relatively shallow waters.

However, successful spawning does not always mean a successful recruitment. A social media post in April 2020 (Hitchin 2020) showed a mass stranding of juvenile $I$. coindetii on a rocky shore in Gourdon, east Scotland. From known information on squid growth in the northeast Atlantic, it is most likely that these juveniles of a little-finger size (approximately 25-40 $\mathrm{mm} \mathrm{ML)} \mathrm{were} \mathrm{descendants} \mathrm{of}$ autumn-winter spawning with an age between 3 and

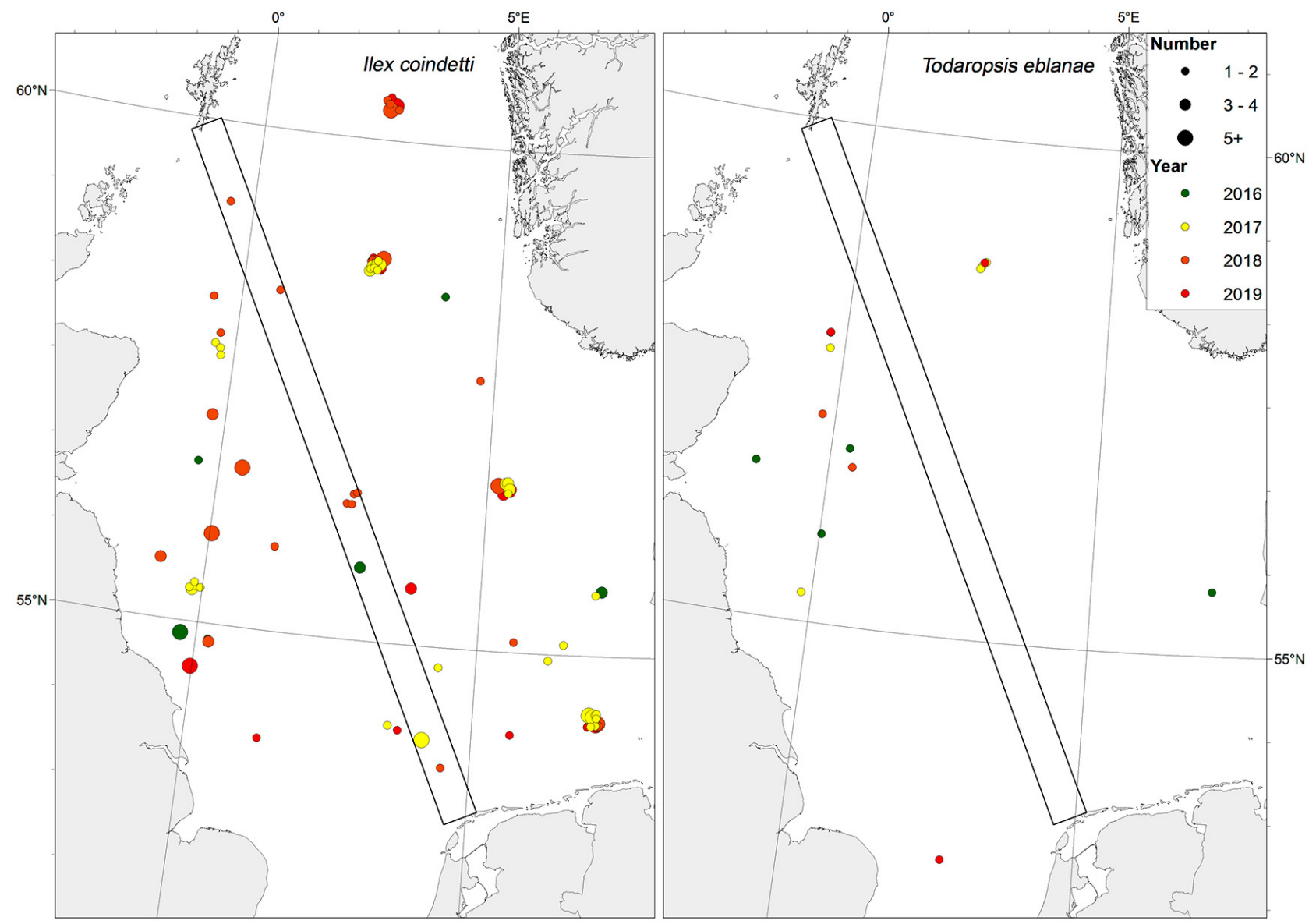

Fig. 3. - Distribution of spawning females of ommastrephid squids. The elongated rectangle shows the position of the transect with its surface corresponding to the area from which oceanographic data were incorporated to describe oceanographic parameters. 
5 months. In April the summer-spawners would be around 9 months old and $>120 \mathrm{~mm}$ ML (González et al. 1996, Oesterwind et al. 2019). Oesterwind et al. (2020) observed in the North Sea specimens with an estimated hatching date at the beginning of December but could not exclude immigration from surrounding areas with warmer waters. The stranded specimens potentially might be born elsewhere and arrived in the coldest period in surface waters of the North Sea (oceanographic winter is March-April) (Høyer and Karagali 2016). Temperatures below thermal tolerance of juveniles of this generally subtropical species could be a reason for their stranding. It is also possible that this stranding was the result of severe storms, particularly if strong winds were from the northeast/east, forcing small, weak swimmers onto Scottish shores. Or, as was hypothesized in the case of the ommastrephid seven star flying squid (Martialia hyadesii) at New Island, Falkland Islands (Nolan et al. 1998), mass stranding could be due to temporal shifts in frontal zones between currents. Another possibility is that they were born in winter in more southern waters and entered the North Sea with the fair current going there from the northern Bay of Biscay through the English Channel (Cooper 1960, Paramor et al. 2009). However, all these theories are purely speculative and need further investigation.

Another successful example of ommastrephid squid adaptation to shallow water seas with semiclosed circulation is Todarodes pacificus, an ecological equivalent of Illex that lays its eggs in the Tsushima Strait, to be developed in the pycnocline and brought into the Sea of Japan with warmer and more saline water of the Kuroshio, the Tsushima Current and the East Korea Warm Current along Japanese coast (Puneeta et al. 2017). The returning branch is composed of the Liman, North Korea and Central Japan Sea currents, which bring fresh and cold water along the Asian coast to the south (Uda and Morgan 2020). A reproductive strategy of I. coindetii is entirely different from that of congeneric ommastrephids inhabiting open shelves of the Atlantic Ocean. For example, I. argentinus inhabiting the southwest Atlantic forages on the Patagonian shelf and upon maturation migrates north, gradually descending deeper and deeper until 700 to $800 \mathrm{~m}$ at $42^{\circ} \mathrm{S}$ (Arkhipkin 1993). Its exact deep-sea spawning grounds off Uruguay and north Argentina are unknown. I. illecebrosus reproduces in the Gulf Stream, which carries its egg masses and juveniles to depths greater than $1000 \mathrm{~m}$ northward to the future foraging area (O'Dor and Dawe 2013). So far, no Illex populations/stocks are described to live entirely on the shelf except summer-spawning $I$. argentinus. However, even in this case it is unknown where the egg masses develop and possibly it might be in a warm Brazilian current flowing above the continental slope (Nigmatullin 1989). It seems that our results in combination with Oesterwind et al. (2020) describe the first Illex stock that performs its life cycle completely in shelf waters.
In conclusion, a combination of climate changes that lead to gradual warming of waters of the North Sea and the suitability of its circulation for pelagic egg masses to develop with minimum risk to be washed onshore resulted in successful settlement of this new reproductive area by ommastrephid squids. There are more semi-enclosed shallow seas in the world where water circulation and permanent thermocline might permit oceanic ommastrephid squids to reproduce. Such expansions of reproductive range as exemplified by I. coindetii (and possibly earlier by $T$. eblanae) in the North Sea might happen again in other areas due to changing ocean conditions.

\section{ACKNOWLEDGEMENTS}

The authors sincerely thank two anonymous reviewers for their invaluable comments.

\section{FUNDING}

This research received no specific grants from funding agencies in the public, commercial or notfor-profit sectors.

\section{REFERENCES}

Arkhipkin A. 1993. Age, growth, stock structure and migratory rate of pre-spawning short-finned squid Illex argentinus based on statolith ageing investigations. Fish. Res. 16: 313-338. https://doi.org/10.1016/0165-7836(93)90144-V

Belcari P., Piatkowski U., Zumholz, K., et al. 2015. Todaropsis eblanae (Ball, 1841). In: Jereb P., Allcock A.L., Lefkaditou E., Piatkowski U., Hastie L.C., Pierce G.J. (eds), Cephalopod biology and fisheries in Europe: II. Species Accounts. ICES Cooperative Research Report, 325, pp. 207-218.

Calow P. 1999. Blackwell's Concise Encyclopedia of Environmental Management. Blackwell Publishing, Oxford, UK.

Cooper L.H.N. 1960. The water flow into the English Channel from the South-west. J. Mar. Biol. Ass. U.K. 39: 173-208. https://doi.org/10.1017/S0025315400013242

Doubleday Z.A., Prowse T.A., Arkhipkin A., et al. 2016. Global proliferation of cephalopods. Curr. Biol. 26: R406-R407. https://doi.org/10.1016/j.cub.2016.04.002

Drew G. 1911. Sexual activities of the squid, Loligo pealii (Les.). I. Copulation, egg-laying and fertilization. J. Morphol. 22: 327-359. https://doi.org/10.1002/jmor.1050220207

ESRI. 2011. ArcGIS Desktop: Release 10. Redlands, CA: Environmental Systems Research Institute.

FAO. 2020. Global Capture Production (online query). Available at: http://www.fao.org/fishery/statistics/global-capture-production/en

Golikov A.V., Sabirov R.M., Lubin P.A., et al. 2012. Changes in distribution and range structure of Arctic cephalopods due to climatic changes of the last decades. Biodiversity 14: 28-35. https://doi.org/10.1080/14888386.2012.702301

González Á.F., Castro B.G., Guerra Á. 1996. Age and growth of the short-finned squid Illex coindetii in Galician waters (NW Spain) based on statolith analysis. ICES J. Mar. Sci. 53: $802-810$ https://doi.org/10.1006/jmsc.1996.0101

González Á.F., Guerra Á. 1996. Reproductive biology of the short-finned squid Illex coindetii (Cephalopoda, Ommastrephidae) of the Northeastern Atlantic. Sarsia 81: 107-118. https://doi.org/10.1080/00364827.1996.10413616

Grimpe G. 1925. Zur Kenntnis der Cephalopodenfauna der Nordsee. Wissenschaftliche Meeresuntersuchungen. Abt. Helgoland 16: 1-122.

Hastie L.C., Joy J.B., Pierce G.J., Yau C. 1994. Reproductive biology of Todaropsis eblanae (Cephalopods: Ommastephidae) in Scottish Waters. J. Mar. Biol. Ass. U.K. 74: 367-382. https://doi.org/10.1017/S0025315400039394 
Hitchin B. 2020. https://www.facebook.com/search/top/?q=illex\&epa=SEARCH_BOX, posted 8th April 2020, accessed 15th July 2020.

Høyer J.L., Karagali I. 2016. Sea surface temperature climate data record for the North Sea and Baltic Sea. J. Clim. 29: 2529-2541. https://doi.org/10.1175/JCLI-D-15-0663.1

ICES. 2018. ICES Fisheries Overviews: Greater North Sea Ecoregion: https://doi.org/10.17895/ices.pub.4647

Jereb P., Koutsoubas D., Belcari P., et al. 2015. Illex coindetii (Vérany, 1839). In: Jereb P., Allcock A.L., Lefkaditou E., Piatkowski U., Hastie L.C., Pierce G.J. (eds), Cephalopod biology and fisheries in Europe: II. Species Accounts. ICES Cooperative Research Report, 325, pp. 178-192.

Kooij J.V.D., Engelhard G.H., Righton D.A. 2016. Climate change and squid range expansion in the North Sea. J. Biogeogr. 43: 2285-2298. https://doi.org/10.1111/jbi.12847

Laptikhovsky V.V. 2007. New data on spawning and bathymetric distribution of the Patagonian squid, Loligo gahi. Biodiversity Rec. 1: e50 https://doi.org/10.1017/S175526720700560X

Laptikhovsky V. 2011. Ecology of Cephalopod reproduction. LAP Lambert Academic Publishing GmBH \& Co. Saarbrüchen, Germany. 233 pp. (In Russian).

Laptikhovsky V.V. 2013. Chapter VIII. Todarodes sagittatus. In: R.Rosa, G.Pierce, R.O'Dor (eds), Advances in squid biology, ecology and fisheries. Part II Oegopsid squids. Nova Biomedical, NY. pp.223-247.

Laptikhovsky V.V., Murzov S.A. 1990. Epipelagic egg mass of the squid Sthenoteuthis pteropus collected in the tropical eastern Atlantic. Biologiya Morya 3: 62-63.

Lipinski M. 1979. Universal maturity scale for the commercially important squids (Cephalopoda: Teuthoidea). The results of maturity classification of Illex illecebrosus (LeSueur 1821) population for years 1973-1977. ICNAF Res. Doc. 79/II/38 Series 5364.

Moum J.N., Smyth W.D. 2001. Upper Ocean Mixing Processes. Encyclopedia of Ocean Sciences. 6: pp. 3096-3100. New York. Academic Press. https://doi.org/10.1006/rwos.2001.0156

Nigmatullin C.M. 1989. Las especies del calamar mas abundantes del Atlantico sudoeste y sinopsis sobre ecologia del calamar (Illex argentinus). Frente Marit. 5 A: 71-81.

Nigmatullin C.M. 2007. A short review of evolutionary and ecological aspects of biology of squid family Ommastrephidae (Cephalopoda: Teuthida). Proceed. Kazan State Univ. 149: 182-193. (In Russian)

Nigmatullin C.M., Laptikhovsky V.V. 1994. Reproductive strategies in the squid of the family Ommastrephidae (preliminary report). Ruthenica 4: 79-82.

Nigmatullin C.M., Laptikhovsky V.V. 1999. Reproductive biology of the subfamilies Todaropsinae and Todarodinae (Cephalopoda, Ommastrephidae). Ruthenica 9: 63-75.

Nesis K.N. 1985. Oceanic cephalopod molluscs: distribution, life forms and evolution. Moscow, Nauka Press.

Nolan C.P., Strange I.J., Alesworth E., Agnew D.J. 1998. A mass stranding of the squid Martialia hyadesi Rochebrune and Mabille, 1889 (Teuthoidea: Ommastrephidae) at New Island, Falkland Islands. S. Afr. J. Mar. Sci. 20: 305-310. https://doi.org/10.2989/025776198784126197

O’Dor R.K., Balch N. 1984. Properties of Illex illebrosus egg masses potentially influencing larval oceanographic distribution. NAFO SCR Doc. 84/IX/102 Serial No N899. $6 \mathrm{pp}$.

O’Dor R.K., Dawe E.G. 2013. Illex Illecebrosus, northern shortfin squid. In: R.Rosa, G.Pierce, R.O'Dor (eds) Advances in squid biology, ecology and fisheries. Part II Oegopsid squids. Nova Biomedical, NY. pp. 73-108.

Oesterwind D., Schaber M. 2020. First evidence of Illex coindetii in the Baltic Sea and Kattegat. Thalassas. 36: 143-147. https://doi.org/10.1007/s41208-019-00178-8

Oesterwind D., ter Hofstede R., Harley B., et al. 2010. Biology and meso-scale distribution patterns of North Sea cephalopods. Fish. Res. 106: 141-150. https://doi.org/10.1016/j.fishres.2010.06.003

Oesterwind D., Piatkowski U., Brendelberger H. 2015. On distribution, size and maturity of shortfin squids (Cephalopoda, Ommastrephidae) in the North Sea. Mar. Biol. Res. 11: 188-196. https://doi.org/10.1080/17451000.2014.894246
Oesterwind D., Barrett C., Bobowski B., et al. 2019. Trial study about age reading of North Sea squids. Working Document in: ICES. 2019. Interim Report of the Working Group on Cephalopod Fisheries and Life History (WGCEPH), 5-8 June 2018, Pasaia, San Sebastian, Spain. ICES CM 2018/ EPDSG:12: 188-194.

Oesterwind D., Bobowski B.T.C., Brunsch A., et al. 2020. First evidence of a new spawning stock of Illex coindetii in the North Sea (NE-Atlantic). Fish. Res. 221: 105384 https://doi.org/10.1016/j.fishres.2019.105384

O'Shea S., Bolstad K.S., Ritchie P.A. 2004. First records of egg masses of Nototodarus gouldi McCoy, 1888 (Mollusca: Cephalopoda: Ommastrephidae), with comments on egg-mass susceptibility to damage by fisheries trawl. N.Z. J. Zool. 31: 161-166. https://doi.org/10.1080/03014223.2004.9518369

Paramor O.A.L., Allen K.A., Aanesen M., et al. 2009. MEFEPO North Sea Atlas. University of Liverpool.

Pascual S., González Á., Arias C. Guerra Á. 1996. Biotic relationships of Illex coindetii and Todaropsis eblanae (Cephalopoda, Ommastrephidae) in the Northeast Atlantic: Evidence from parasites. Sarsia 81: 265-274. https://doi.org/10.1080/00364827.1996.10413624

Puneeta P., Vijai D., Yamamoto Y. et al. 2017. Structure and properties of the egg mass of the ommastrephid squid Todarodes pacificus. PLOS ONE 12(8): e0182261. https://doi.org/10.1371/journal.pone.0182261

Rasero M., González Á.F., Guerra Á. 1995. Spawning pattern and fecundity of the ommastrephid squid Todaropsis eblanae in Northeastern Atlantic waters. ICES Annual Science Conference. C.M. 1995/ K: 9, 14 pp +6 figs.

Rasero M., González Á.F., Castro B.G., Guerra Á. 1996. Predatory relationships of two sympatric squids Todaropsis eblanae and Illex coindetii (Cephalopoda: Ommastrephidae) in Galician waters (NW Spain). J. Mar. Biol. Ass. U.K. 76: 73-87. https://doi.org/10.1017/S0025315400029027.

Ringvold H., Taite M. 2018. Using citizen science to obtain data on large, floating gelatinous spheres from NE Atlantic, attributed to egg mass of ommastrephid squid (Oegopsida, Cephalopoda, Mollusca). Mar. Biol. Res. 14: 672-681. https://doi.org/10.1080/17451000.2018.1504165

Rodhouse P.G.K., Pierce G.J., Nichols O.C., et al. 2014. Environmental effects on cephalopod population dynamics: implications for management of fisheries. Adv. Mar. Biol. 67: 99-233. https://doi.org/10.1016/B978-0-12-800287-2.00002-(

Roper C.F.E., Nigmatullin C., Jereb P. 2010. Family Ommastrephidae. In: Jereb P., Roper C.F.E. (eds), Cephalopods of the world. An annotated and illustrated catalogue of species known to date. Volume 2. Myopsid and Oegopsid Squids. FAO Species Catalogue for Fishery Purposes. No. 4, Vol. 2. Rome, FAO. pp. 269-347.

Sabirov R.M., Golikov A,V., Nigmatullin C.M., et al. 2012. Structure of the reproductive system and hectocotylus in males of lesser flying squid Todaropsis eblanae (Cephalopoda: Ommastrephidae). J. Nat. Hist. 46: 1761-1778. https://doi.org/10.1080/00222933.2012.700335

Salman A., Laptikhovsky V. 2002. First occurrence of egg masses of Loligo forbesi (Cephalopoda: Loliginidae) in deep waters of Aegean Sea. J. Mar. Biol. Ass. U.K. 82: 925-926. https://doi.org/10.1017/S0025315402006392

Sato N., Kasugai T., Munehara H. 2014. Spermatangium formation and sperm discharge in the Japanese pygmy squid Idiosepius paradoxus. Zoology 117: 192-199. https://doi.org/10.1016/j.zool.2014.02.001

Sea Snack Norway. 2019. "Mystery on large gelatinous spheres solved!" Sea Snack Norway Press Release, 17 Sep. 2019. Available at: https://buzzingkid.no/Images/engpressegelb2019.pdf

Schlitzer R. 2014. Ocean Data View. http://odv.awi.de.

Soeda J. 1956. Studies on the ecology and the breeding habits of the squid, Ommastrephes sloani pacificus (Steenstrup). Bull. Hokkaido Reg. Fish. Res. Lab 14: 1-24.

Squires Z., Wong B.B.M., Norman M.D., et al. 2014. Multiple paternity but no evidence of biased sperm use in female dumpling squid Euprymna tasmanica. Mar. Ecol. Prog. Ser. 511: 93-103. https://doi.org/10.3354/meps10898

Staaf D.J., Camarillo-Coop S., Haddock S.H.D., et al. 2008. Natural egg mass deposition by the Humboldt squid (Dosidicus gigas) in the Gulf of California and characteristics of hatchlings and paralarvae. J. Mar. Biol. Ass. U.K. 88: 759-770. https://doi.org/10.1017/S0025315408001422 
Uda M., Morgan J.R. 2020. Sea of Japan. Encyclopaedia Britannica. https://www.britannica.com/place/Sea-of-Japan

Villanueva R., Quimtana D., Petroni G., Bozzano A. 2011. Factors influencing the embryonic development and hatchling size of the oceanic squid Illex coindetii following in vitro fertilization. J. Exp. Mar. Biol. Ecol. 407: 54-62.

https://doi.org/10.1016/j.jembe.2011.07.012 